\title{
Počátky muslimských menšin ve střední Evropě*
}

\author{
LuBOŠ KROPÁČEK**
}

\section{The Making of Muslim Minorities in Central Europe}

\begin{abstract}
The research has been focused on Central Europe in the "long $19^{\text {th }}$ century". As to the previous history, a small community of (Lipka) Tatars is attested in Poland since more than 600 years. For Hungary both Latin and Arabic sources point even deeper but the data about the Muslims' identity and history are rather vacillating. Better information is available concerning the Ottoman expansion reaching as far as Southern parts of present-day Slovakia. In the $19^{\text {th }}$ century relations between Christian Europe and Islam changed on both sides, which encouraged Muslims to settle even in countries of their erstwhile enemies. The paper gives an account of conversions to Islam and of stimuli for Muslims' migration to the Habsburg monarchy and its successor states. They comprise a demographic factor and the Austrian occupation and annexation of Bosnia, followed by the Laws on Islam adopted in 1912 and 1916. The paper concludes with a brief outline of the rise of new Muslim communities in the region after the world wars.
\end{abstract}

Keywords: Ottoman expansion, converts to Islam, migrations, Muslim communities, Bosnia

\section{Dějiny a kontext}

Diskuse o islámu v Evropě se často věnují jen vymezenému užšímu územnímu celku. Pokud se zaměřují na širokou celokontinentální perspektivu, mají před sebou tři velká uskupení se zřetelnou geografickou a historickou osobitostí. Na východě Evropy islám šiřili zvláště Tataři, na Balkáně expanze Osmanské říše a v západní a severní Evropě ustavili muslimské komunity až přistěhovalci po 2 . světové válce. $V$ evropských zemích západního Středomoří se přítomnost muslimů sice spojuje s připomínkami středověkých dějin, avšak dnešní muslimské menšiny vznikají až v současnosti, a to rovněž imigrací, v nemalé míře ilegální. Encyklopedie islámu rozlišuje v prvotním třídícím schématu muslimské komunity ve východní Evropě ustavené již dávno, k nimž řadí také starší skupinky v Polsku a Mad’arsku, od přistěhovaleckých komunit v západní Evropě. Někdy se také pro náš první a druhý blok, kdy islamizace absorbovala v jejich jádrech významné počty místního obyvatelstva, používá výrazu autochtonní. Přistěhovalecký islám, nahlížený převážně jako transplantovaný ze zámoří, platí pak za alochtonní. Dnes jej sdílejí leckdy již třetí nebo i čtvrté generace přistěhovaleckých rodin, které sice zapustily pevné kořeny v nové, evropské vlasti, většinou však nezpřetrhaly některé vazby s oblastmi původu a jejich integrace v evropských společnostech není bez problémů. Termín si proto uchovává relativní oprávnění.

Vymezením „střední Evropa“ rozumíme v této studii především oblast někdejšího Rakouska-Uherska a nástupnických států po jeho rozpadu. V přehledu Encyklopedie islámu není pojmenována a je jí věnována jen menší, selektivní pozornost, zvláště

\footnotetext{
* Stat’ byla zpracována v rámci řešení projektu GA ČR P405/10/J060.

** Prof. Luboš Kropáček, Filozofická fakulta Univerzity Karlovy, Náměstí Jana Palacha 2, 11638 Praha 1. E-mail: kroplaff@praha1.ff.cuni.cz
} 
v souvislosti s arabskými středověkými prameny. O muslimských menšinách v Československu se nehovoří vůbec. ${ }^{1}$ Je ovšem nepopiratelné, že střední Evropa na mapě rozšiření islámu zůstává dnes skutečně - s výjimkou Rakouska - téměř nevyplněným prostorem, $\mathrm{k}$ němuž se sice sbíhalo působení všech tří islamizačních uskupení, ale přes početné rozběhy jej v podstatné míře nedosáhlo.

Malé skupiny Tatarů se usadily v krajích, které jsou dnes součástí Polska, ve starší vlně z povolžského chánátu již před 600 lety a pak v druhé vlně od Krymu v 17.-18. století. Jejich dějiny a etnografické charakteristiky, včetně zvláštních rysů jejich islámu, byly již popsány a analyzovány v několika odborných monografiích. ${ }^{2}$ Někteří Tataři konvertovali ke křest̉anství, jiní si uchovali islámskou identitu v napojení na ústřední muftiát v litevském Vilnu (Vilnius).

Tatarští muslimové se účastnili po boku Poláků jako zvláštní jednotka vícerých válek, včetně bitvy u Grunwaldu. Pozoruhodným kulturním dílem jsou jejich tři dřevěné mešity v białystockém vojvodství z 18. a 19. století. Jinde bychom v islámské sakrální architektuře tento stavební materiál nenašli, dřevo se tam totiž nedostává; zde v Polsku zaznamenáváme naopak kulturní blízkost křestanským kostelům.

V Uhrách je v dějinách doložena přítomnost muslimů přišlých jak z východu, tak později od jihu. Arabské prameny se zmiňují o Mad’arech (Madžar, al-Madžaríja) již v jejich někdejší vlasti severně od Černého moře, a pak v Uhrách (Madžaristán či Unqúríja). Islám přinášely do Panonie zvláště imigrující kočovné kmeny, patřící převážně k turkickým etnikům, jako byli Baškirové (Bašqird), Pečeněgové, Kypčaci (Kumáni, Polovci), Chvárezmijci a Turkomani. Když král Štěpán I. zvolil pro zem křestanství, někteří k němu přestoupili. Islám si však uchoval početné vyznavače, jak nejpodrobněji dosvědčuje zpráva o jejich způsobu života, kterou sepsal po tříletém pobytu v polovině 12. století cestovatel z Andalusie Abú Hámid al-Gharnátí. ${ }^{3} \mathrm{O}$ století později se tito místní muslimové zapojili do bojů proti vpádu Tatarů, tehdy ještě neislamizovaných. Za Anjouovců na počátku 14. století byl islám v Uhrách vytlačován rozhodnou christianizací. Uzavřela se tak první fáze muslimské přítomnosti v zemi, dokumentovaná poměrně bohatě prameny v arabštině a latině. ${ }^{4}$

Následující fázi, islamizaci z Balkánu, dávala dynamiku expanze Osmanské říše, její válečné konfrontace s místními křestanskými státními útvary a úpravy vztahů s nimi jako vazaly (Sedmihradsko) a také správní a hospodářská politika na okupovaných územích. Vrcholnou úroveň vztahů představovaly války a jednání s habsburskou monarchií.

$\overline{1}$ Encyclopaedia of Islam, 2. vyd., (krátce EI-2) vol. VII, Leiden: E. J. Brill. [1993]. heslo Muslimun. Novější internetová Wikipedie věnuje již islámu v České republice a na Slovensku samostatná hesla.

2 Zvláště Borawski, P. - Dubiński, A. [1986]; Tyszkiewicz, J. [1997]; Tyszkiewicz, J. [1998]; Miskiewicz, A. [1990]. Bohaté, přehledně utř́iděné informace podávají stati Dziekan, Marek M.: Historia i tradycje polskiego islamu, a Nalborczyk, Agata: Status prawny muzułmanów i jego wplyw na organizacje ich życia religijnego. In. Parzymies, Anna [2005], s. 197-228 a 229-238.

3 Jeho zprávě věnoval v roce 1955 tři studie Ivan Hrbek: Nový arabský pramen o východní a střední Evropě (Abú Hámid al-Andalusí). Československá etnografie II/2, s. 157-175; Arabico-Slavica. Abú Hámid al-Andalusí und sein Werk „Mu’rib“. Archív Orientální 23, s. 109-135; Ein arabischer Bericht über Ungarn (Abú Hámid al-Andalusí al-Garnátí, 1080-1170). Acta Orientalia V, Fasc. 3. Budapest, s. $205-230$.

4 Tematiku zpracovávali početní evropští odborníci, významnými pracemi přispěli zvláště Vladimir F. Minorsky z Ruska, polský orientalista Tadeusz Lewicki a český Ivan Hrbek. Přehled problematiky a pramenů uvádí EI-2, svazek V, heslo Madjar, Madjaristan, s. 1010-1024. 
Turci na vrcholu své vojenské moci za Süleymana Nádherného a jeho nástupců pronikli Uhrami až do jižních krajů dnešního Slovenska. Některá slovenská území na čas př́mo začlenili do řiše: po roce 1541 čtyři sandžaky budínského vilájetu a po roce 1663, kdy dobyli pevnost Nové Zámky, zde zřídili zvláštní nový vilájet. Byl to rok největšího rozšíření tureckého panství ve střední Evropě. Nejdrastičtější dopad na obyvatelstvo měly však pustošivé nájezdy daleko přes dohodnuté hranice: v první vlně už v roce 1530, a potom v době vrcholné moci. Nájezdy ohrožovaly středoslovenská báňská města a přesáhly až na východní Moravu. Tyto děje s proměnlivým územním rozsahem trvaly až do zpětného dobytí Nových Zámků (1685), či až do mírové smlouvy uzavřené v Karlovcích (Karlofča, 1699), kdy Osmanská řriše musela postoupit téměř celé Uhry císaři. ${ }^{5}$

Mírová smlouva z Požarevce (1718) postupovala císaři další uherská území, ale zároveň přiznávala tureckým muslimům pod jeho vládou svobodu vyznání a obchodu a právo zakládat faktorie a osady. Tyto svobody platily pouze pro sultánské, nikoli habsburské poddané. Za dalších válek přestaly platit. Krátké trvání měly již dříve mešita a úřad imáma zřízené ve Vídni pro osmanské představitele a obchodníky po navázání diplomatických styků s Istanbulem v roce $1606^{6}$ a samozřejmě snahy českých stavů, které pozvaly Turky v roce 1620 za svého povstání do Prahy jednat o možnostech spojenectví proti Habsburkům.

Dlouhodobě převládaly negativní obrazy soka. Místní obyvatelstvo poddané cizí okupační moci bylo paušálně označováno termínem reaya, který je v konotaci s významem „stádo“ v evropském vědomí vnímán jako pejorativní. Smýšlení obyvatel bylo samozřejmě určováno jeho reálným postavením z hlediska daní, odvodů (devširme křestanských hochů), míry náboženských a osobních svobod a obecně hospodářských a politických poměrů. Rozsáhlé utrpení přinášely pustošivé nájezdy, doprovázené ničením, vypalováním vesnic, odváděním a zotročováním množství zajatců i jinými krutostmi. Někteří obyvatelé z okupovaných a napadaných území Uher volili emigraci do bezpečnějších území. Tak například větší počet chorvatských rodin se usadil ve vesnicích na jihozápadě Slovenska; podle některých interpretací je se zřetelem k jejich náboženství a k slovanskému jazyku k takovéto emigraci osmanské úřady přímo povzbuzovaly, patrně s cílem zajistit si zpravodajské služby. Vyzvědačství existovalo na všech stranách a bylo také vždy přísně trestáno. Obecně platí, že osmanští vládci se nijak výrazně nesnažili do Uher přesídlovat turecké rodiny, jak to prováděli v jižněji položených balkánských zemích, a přestupů na islám tu rovněž bylo jen málo. Osmanům šlo více o materiální prospěch jejich byrokratické správy. Jejich nadvláda stabilizovala určité poměry společností a v mnoha směrech paralyzovala možnosti jejich pokroku v době, kdy na západě Evropy vyvstávaly horizonty zřetelného rozvoje.

Turci dvakrát obléhali Vídeň (1529 a 1683). Na porážce oblehatelů u Vídně se podíleli i čeští šlechtici (Zdeněk Kaplî́r ze Sulevic) a vojáci a kromě německého vojska

5 Dobré, přehledné vylíčení složitých dějin podává monografie Horváth, P. a Kopčan, Vojtech [1971]. Po úmrtí Vojtecha Kopčana (1996) se nikdo ze slovenských historiků působením Turků na Slovensku tak intenzivně nezabýval. V poslední době se archeolog Zoltán Drenko věnoval archeologickému výzkumu ve Fil'akovu a organizoval výstavu Turci na Slovensku, která postupně v Komárně (2008) až Bratislavě (2010) předvedla výběr islámských artefaktů zachovaných Turky na jižním Slovensku.

6 Zprávy o nejstarších rakousko-tureckých vztazích soustřed’ovali zvláště Smail Balič a badatel o islámském právu R. Potz. Zde uvádíme podle údajů v kapitole Agaty Nalborczyk v Parzymies, A. [2005], s. 282 . 
Karla Lotrinského také slavné polské vojsko krále Jana Sobieského. Turecká hrozba byla pocitována v regionu všude, a to po řadu generací, a zůstává v literárních i výtvarných dílech a v historické paměti a lidové mentalitě v různých podobách živa dodnes. ${ }^{7} \mathrm{~V}$ dalších staletích válečných střetů císařská vojska krok za krokem postupně zatlačovala osmanské protivníky Balkánem na jih. ${ }^{8}$ Důležitou roli sehrál rakousko-uherský zásah v Bosně, který svými zprvu jistě neočekávanými důsledky silně ovlivnil další osudy islámu v zemích podunajské monarchie. Bosenskému faktoru věnujeme zvláštní podkapitolu.

Svým časovým vymezením se jádro této studie zaměřuje na období konečných fází „dlouhého 19. století“ až do první světové války. Stejně jako vymezení zeměpisné vyžaduje si naše téma muslimské př́itomnosti některé přesahy vytyčených hranic ve faktografii, v komparacích a v úvahách. Třetí typ uskupení, tj. nový, přistěhovalecký islám po 2. světové válce, se ve studované oblasti vyskytl v plné síle jenom v Rakousku, protože v jiných zemích bránila jeho ustavení železná opona. V našem zkoumaném období si zasluhují pozornost jenom počáteční podoby sociálních a kulturních skutečností, které se později, zvláště koncem 20. století, rozvinuly do rozměrů závažných mezikulturních, mezináboženských, či - v huntingtonovské dikci - mezicivilizačních témat.

\section{„Dlouhé století““ proměn}

Ve vztazích mezi Evropou a islámem - významném tématu současnosti - můžeme v dějinách sledovat výrazné posuny v percepcích druhého i v praktickém chování. Odráží se tu i rozdílně orientovaná historická pamět. ${ }^{9}$ Př́kré kritiky, ba hanobení islámu ve stř̌edověké Evropě jsou dnes již dobře zmapovány. ${ }^{10} \mathrm{~V}$ raném novověku nahradili „saracény“ v obrazu nepř́tele Turci. Pokud by se je podařilo obrátit na křestanství, mohli by být žádoucími spojenci proti Habsburkům, soudil i Jan Ámos Komenský. Zmírnění negativního pohledu na islám přinesly jednak slábnutí turecké hrozby po porážce u Vídně, jednak stoupající znalosti o islámu a o muslimech. Na prahu osvícenství zapůsobil Gotthold Ephraim Lessing podobenstvím Moudrého Nathana o třech prstenech, kdy pravost má prokázat soutěžení v konání dobra. ${ }^{11}$

Proměny evropských pohledů na islám lze sledovat po celé 19 . století. ${ }^{12}$ Měly zpočátku podobu romantickou a básnickou (Johann Wolfgang Goethe), filosofickou (Friedrich Schleiermacher) i teologickou (Johann Adam Möhler). Velký krok vpřed pak učinila

7 O tom, jak se vytvářel a vyvíjel stereotypní obraz tureckého „mohamedánského“ nebezpečí, podává podrobný, fundovaný výklad monografie Tomáše Rataje [2002].

8 Literatura o Osmanech na Balkánu je dnes velmi rozsáhlá. Česky je k dispozici studie Eduarda Gombára [1999], Adama Pallmera [1996] a početné práce původní i přeložené reagující na konflikty po rozpadu Jugoslávie. Studie Coles, Paul [1968] ukázala, jak turecké nebezpečí pomohlo zvýšit soudržnost v Evropě a jak sociálně poznamenalo Uhry. O trvajícím zájmu o historické pozadí svědčí několikeré reedice rozsáhlé (1018 stran) syntetické monografie Stavrianos, L. S. The Balkans Since 1453 od 1. vydání 1958 po reprint z r. 2009, London: Hurst.

9 Z velmi bohaté literatury k tomuto tématu upozorňuji na Kropáček, Luboš. [2002].

10 Tolan, John V. [2002]. Saracens. Islam in the Medieval European Imagination. New York: Columbia UP.

11 Tuto formulaci výzvy přijal jako východisko k úsilí o mezináboženský mír a sblížení žák Hanse Künga, spolupracující na jeho projektu světového etosu: Kuschel, Karl-Josef. [1998].

12 Standardní výklady přinesl Albert Hourani [1991a]. Reflexe o evropském myšlení a náboženství v 19. století podává v češtině sborník Jiří Hanuš (ed.). [2002] a velký počet dalších studií. Nový impuls bádání se odráží v materiálech mezinárodní vědecké konference Náboženství v českých zemích v „dlouhém 19. století (1780-1918)“, kterou pořádala Fakulta humanitních studií UK spolu s Muzeem města Duchcov v květnu 2010. 
orientalistika: bádání o islámu konečně stanulo na solidních vědeckých základech. ${ }^{13}$ Islám byl v obecném povědomí očištován od starých hanobících stereotypů, ale zároveň se rozvíjely nové, zvláště ahistorická absolutizace jeho neměnnosti a všudypř́tomnosti v životě orientálních společností, již později zahořkle, ale působivě podrobil kritice Edward Said.

Pozměněné vědomí o dědičném soupeři, jehož klíčová mocnost byla tlačena k perspektivám zániku („východní otázka“), otevíralo prostor k některým způsobům jednání s muslimy, jaké dříve těžko připadaly v úvahu. Šlo například o širší možnosti jak je zaměstnávat a nechat usadit v bezprostředním sousedství. Cestu v tomto směru ukazovaly i v této době triumfující koloniální zábory: ruské na Kavkaze a ve Stř̌ední Asii, anglické, francouzské a německé v Africe a některých oblastech Asie, nizozemské v Indonésii a italské rovněž v Africe, realizované ovšem opožděně. Rakousko-Uhersko si zámořské kolonie přímo nezískalo, avšak v některých muslimských oblastech, jež si dosud nepřivlastnily konkurenční mocnosti, projevovalo svůj zájem. Manifestovali jej dobrodružně naladění zdatní jedinci, kteří se prosazovali do významných správních nebo hospodářských funkcí, např́klad v Súdánu.

Sílící sekularismus a nacionalismus doprovázely leckdy kromě slábnutí zbožnosti také útoky mocenského establishmentu na církev, zvláště římskokatolickou. Střední Evropu ovlivňoval Bismarckův Kulturkampf, zčásti také kampaň ve Francii z roku 1905 a rostoucí nechư $\mathrm{k}$ austrokatolicismu. S poměrně širokou občanskou podporou se protivatikánské postoje zřetelně vyhrotily v Československu hned po jeho vzniku na troskách habsburské monarchie. Tyto trendy se promítly také do diferencovaných postojů církve, reformních i úporně konzervativních, včetně pohledů na islám. Dekretem Lamentabili z roku 1907, tvrdě kaceřujícím katolické modernisty, Pius X. zároveň vyloučil přijetí islámu jako zjevení. Teprve po delším časovém odstupu bylo toto stanovisko některými teology zmírňováno. ${ }^{14}$

Jako př́íklad vlídného oceňování muslimů v době, kdy ještě nebyl formulován pojem dialogu, lze uvést působení katolického kněze, arabisty a objevitele Aloise Musila, který pocházel z Moravy, a k němuž se hlásí Češi i Rakušané. Od roku 1895 do první světové války procestoval arabské země Blízkého východu s primárním cílem srovnávat tamní způsob života s biblickým. Jeho početné spisy znamenají velký přínos vědecký a také morální jako svědectví o možnosti dobrých lidských mezináboženských vztahů v dějinách i současnosti. Muslimové v Československu se domnívali, že Musil v Jordánsku přijal islám. Rozsáhlý archiv jeho korespondence ve Vyškově, jenž se dnes digitalizuje, však svědčí o tom, že až do smrti zůstal oddaným katolickým knězem. ${ }^{15}$

V muslimských společnostech přinášelo 19. století rovněž početné změny, vnímané převážně jako modernizace. Rostl zájem o Evropu. Ta byla od pozdního středověku

13 Metodické př́stupy zakladatelských osobností islamologie vyložil významný religionista Jacques Waardenburg [1963].

14 Vstř́cnější interpretaci islámu jako typu zjevení nabídli např́íklad J. Moltmann. J. B. Metz, C. Geffré a Kenneth Cragg. V duchu Pia X. odmítají dnes na půdě katolicismu jakýkoli mezináboženský dialog jen lefebvristé.

15 Kropáček, Luboš [1995]. V současnosti připravuje Pavel Žđárský vydání zatím nepublikované Musilovy práce Ze světa islámu, sepsané po roce 1940. V zárí 2010 obhájil na Cyrilometodějské teologické fakultě v Olomouci ThLic. Jaroslav Franc doktorskou disertaci Alois Musil a hledání pramenů monoteismu: na cestě od pokojného soužití beduínů, muslimů, východních a západních křestanů k náboženskému a ekumenickému dialogu (248 stran, zatím nevydána). 
v klimatu stagnace sebestředně přehlížena, avšak nyní, kdy prokázala svou sílu, vícestrannou převahu a prosperitu, lákala k napodobování. Podle evropských vzorů se reformovaly státní instituce (osmanské tanzimat) a k větší efektivitě modernizovaly armády a ekonomika. Do země byli zváni evropští experti a do Evropy byly vysílány studijní mise; slavná je zvláště egyptská, kterou vedl jako imám významný intelektuál Rifá’a Ráfi’ at-Tahtáwí. V druhé polovině století muslimové ovšem s obdivem mísili rostoucí hněv nad finančním kořistěním a koloniální politikou evropských mocností. V panislámském duchu se proti ní snažil sjednocovat úsilí Džamáluddín al-Afghání. Ve snaze o uchování vlastní kulturní identity se muslimové učili nově přebírat své tradiční hodnoty a rozlišovat mezi potřebnou modernizací a nežádoucím pozápadňováním, westernizací. ${ }^{16}$

Podle středověkého názoru Evropa představovala převážně dár al-harb, „oblast války“, kde lze očekávat násilné střety. Muslimové mají žít v dár al-islám, kde se těší míru. Do dár al-harb by vůbec neměli jezdit a rozhodně by se tam neměli usídlovat. Od dob kř́̌žových válek si lukrativní obchod mezi Evropou a muslimským Orientem téměř monopolizovala italská města, křestané a Židé, muslimové si cesty do Evropy mentálně i de iure zakazovali. Takovýto postoj bral v 19. století za své. Zatímco Evropané hledali prospěch $\mathrm{v}$ různých formách podnikání v zemích muslimského Východu již po řadu generací, muslimové se ve světě sjednocovaném kolonizací začínali stěhovat do Evropy až nyní. Mentální a sociální překážky slábly. V současnosti nahrazují horliví muslimští mediální aktivisté, včetně některých radikálů, staré označení Evropy dár al-harb za dár $a d-d a$ 'wa tj. oblast misijního islamizačního úsilí. Je tedy nejen př́ípustné, ale dokonce doporučeníhodné v Evropě se také usazovat.

\section{Faktor demografie}

V dlouhém 19. století má také svůj počátek tendence rozdílného demografického vývoje v Evropě a v muslimských zemích, která dnes vyvolává neklid a obavy z budoucnosti. Evropský stagnující populační vývoj názorně představuje př́klad Francie, která nastoupila cestu industrializace, přičemž postupující dechristianizace společnosti zároveň pomáhala snižovat početnost příslušníků rodiny. Potřebu manuálních a pomocných pracovních sil Francouzi řešili jejich dovozem: z Itálie, ze Španělska a Portugalska a také z Polska a Slovenska. Tuto potřebu zvýšily lidsky i materiálně ničivé dopady světových válek. Avšak železná opona uzavřela východoevropský zdroj. Náhradu poskytli pracovníci dovážení z muslimských zemí Maghribu a vůbec z Afriky, kteří se už za válek osvědčili v armádě.

V muslimských zemích naopak populační křivka nastoupila cestu růstu. K tomu přispívalo zlepšování zdravotnictví, dopravy a komunikací. Tak se v Alžírsku za půlstoletí mezi lety 1861 a 1914 počet obyvatel zdvojnásobil ze 2 na 4,5 milionů. Podobně byl v Egyptě zaznamenán růst od roku 1800 do roku 1914 ze 4 na 12 milionů. V Sýrii, Libanonu a Iráku se rovněž v tomto období odhaduje zřetelný růst, který se odrazil v početné libanonské a syrské emigraci do obou Amerik. ${ }^{17} \mathrm{~V}$ Osmanské říši se zřejmě během století obyvatelstvo rovněž zdvojnásobilo. V roce 1914 zde žilo asi 26 milionů obyvatel, tj. stejně jako v roce 1800 , přičemž území ř́šse se zmenšilo o více než polovinu ztrátou

16 Ke standardním pracím o islámské reformě patří Keddie, Nikki [1968]. Sayyid Jamal al-Din al-Afghani. Berkeley; Rahman, Fazlur [1982]. Islam and Modernity. Chicago; v češtině zatím téma nejzevrubněji zpracoval Kropáček, Luboš [1971]. Moderní islám I. Praha: Univerzita Karlova, s. 39-65.

Hourani, Albert [1991b], s. 293-294. 
nejlidnatějších balkánských území. Stoupající hustota zalidnění se odrážela v urbanizaci. Zajímavým rysem, bohužel spíše vnímaným intuitivně než statisticky podchyceným, byla vyšší porodnost v osmanských křestanských než muslimských rodinách. ${ }^{18}$ Ve 20 . století - a stoupající měrou směrem k dnešku - se tento trend dramaticky obrátil. Na územích říše se ještě v roce 1831 počítaly asi dvě třetiny obyvatel za muslimy, asi $1 \%$ tvořili Židé a necelou třetinu představovali vyznavači různých křestanských denominací. Křestané pak ve vícerých vlnách emigrovali, za první světové války byl drasticky zredukován počet Arménů a v počátcích kemalistické revoluce bylo odsouváno řecké obyvatelstvo při současném přijímání Turků z Balkánu, zprvu živelně, pak smluvně dohodnutou výměnou.

\section{Náboženské konverze a migrace}

Neklidné dějiny středoevropského regionu zahrnovaly v některých dobách také chtěné nebo vynucené změny vyznávané konfese. Někdy šlo o konverze individuální, někdy hromadné ve větších kolektivitách. Motivovaly je různé důvody.

Byla již řeč o christianizaci části Tatarů z první vlny v Polsku. V 16. a 17. století byly naopak zaznamenány emigrace sociniánů z Polska do Osmanské říše, kde byli přijímáni jako lidé „správně vedení“ (mustahdún, muhtadún). Jejich př́íklonu k islámu napomáhala, podobně jako již dříve u balkánských bogomilů či patarenů, jejich antitrinitární teologie odmítající božství a spasitelské poslání Ježíše Krista. V 19. století podnítila jinou vlnu emigrace $\mathrm{v}$ tomtéž směru sympatie $\mathrm{k}$ Turkům jako nepřátelům Ruska a Rakouska, tedy mocnostem, které si rozdělily Polsko. Kníže Adam Czartoryski obstaral roku 1842 pozemky na Bosporu, kde emigranti vystavěli vesnici Adampol, existující s tureckým jménem Polonezköy dodnes. ${ }^{19}$

V Uhrách se někteří muslimové dávali pokřtít již za vlny christianizace za krále Štěpána I. (997-1038), ale mnozí se později vraceli k islámu. V latinských pramenech panuje někdy nejistota, zda některá etnika, např́klad Pečeněgové nebo Kumáni, mají být považována za muslimská (Saraceni, Ismaelitae, Bissermini z madarského Böszörmény „muslim“), nebo křestanská. Náboženská identita nebyla vždy jednoznačná. Někteří křest̉anští autoři, včetně českých, zahrnovali „saracény“ jednoduše mezi pohany. V arabských pramenech se systematizující snaha dát náboženský smysl nemalé množině jmen přistěhovalých kmenů a etnik, které se jazykově sjednocovaly na bázi mad’arštiny, projevuje rozlišením mezi křest̉anskými Madžar a muslimskými Bašqird. Počátkem 14. století král Karel-Robert z Anjou vyzval muslimy bud’ k přijetí křestanství, nebo k odchodu. Některé prvky životního stylu muslimů si nicméně uchovali i ti, kteří se dali pokřtít.

Osmanský okupační či kvazi-protektorátní režim k přestupům na islám nenutil. Přestupovali spíše jen jednotlivci s různou motivací. U mužů bylo nutné podstoupit obřízku (kterou v Polsku někdy prováděli Židé) a muži i ženy si museli podle nového náboženství upravit zevnějšek. Za nejvýznamnějšího konvertitu lze nepochybně označit Ibrahima Müteferriku (1674-1745), původem unitáře z transylvánského Koložváru (dnes Cluj v Rumunsku), jenž zř́idil v Istanbulu první tiskárnu s arabskými literami. Do roku 1742 vytiskl 23 svazků. Pokládají se za turecké inkunábule. Jsou to díla nenáboženská, mimo jiné přinášela osmanským vzdělancům také kopernikánský heliocentrismus.

18 Inalcik, Halil with Quataert, Donald [1994], s. 777-784.

19 Łatka, J. S. [1992]. Adampol. Polska wieś nad Bosforem. Kraków. 
Zvýšenou mobilitu lidí doprovázel rostoucí zájem o druhé náboženství, včetně rozvoje orientalistiky a hodnocení odlišné kultury, nikoli však nutně náboženské přestupy. Docházelo však i ke konverzím v kontextu pestré kariéry. Př́klad dává zvláště Emín Péaša (1840-1892), původně židovský lékař Isaak Eduard Schnitzer z Horního Slezska (Opole a Nysa). Po otcově smrti dala matka tehdy sedmiletého chlapce pokřtít. Působil nejprve jako lékař v muslimských zemích na Balkáně, potom v Egyptě. Není zcela jasné, zda, př́ípadně jak, přijal islám, rozhodně si však dal změnit jméno na Mehmet Emín s dodatkem vysoké hodnosti Paša. Byl delegován do Súdánu, kde mu byla svěřena správa Rovníkové provincie. Mahdistické povstání ji odřízlo od dočasně poražené egyptské správy a Emína samotného přišel roku 1889 odvést Henry Morton Stanley. Celý dobrodružný př́íběh si získal v Evropě velkou pozornost. ${ }^{20}$

Se súdánskou mahdíjí je také spjat životní příběh Rudolfa Slatina (1857-1932). Narodil se ve Vídni v rodině původně židovské, pokřtěné na katolickou. Působil v Súdánu jako guvernér Dárfúru. Za rychlého vzestupu mahdismu přestoupil roku 1883 na islám, prý proto, aby se jeho kontingent vládních sil nepohoršoval, že mu velí křestan. Přijal také muslimské jméno Abdalqádir. O své veřejně deklarované konverzi se zmiňuje i ve svých spisech. Prošel mahdíjí jako zajatec, pak uprchlík, odborník protimahdistické rozvědky a za kondominia generální inspektor Súdánu až do vypuknutí 1. světové války, kdy jako rakousko-uherský občan byl Angličany ze země vypovězen. O jeho židovských kořenech psaly dobová antisemitská publicistika i židovské nekrology. ${ }^{21}$

Do dějin islámu v Uhrách v 19. století patř́i účast některých cizích muslimů na sněmu, který zasedal v Prešpurku (v letech 1802-1848), a také konverze několika představitelů uherské revoluce 1848-1849, kteří po její porážce emigrovali do Osmanské říše. Jako významný orientalista se proslavil Armin Vámbéry (vlastním jménem Hermann Wamberg, 1832-1913), původem z chudé židovské rodiny ve Svätém Juru či Dunajské Stredě. Své jedinečné nadání na jazyky využil při cestách asijskými muslimskými zeměmi a později jako profesor v Budapešti. Není jisté, zda přestoupil na islám, ale choval se a hovořil jako Turek a strojil se jako derviš. Dnes se jeho jménem nazývá slovenskomađarská orientalistická společnost se sídlem v Dunajské Stredě. ${ }^{22}$

Mezi zakladateli vědeckého studia islámu jako náboženství patří ovšem přední místo Ignazi Goldziherovi (1850-1921) z mađarské židovské rodiny. Islamologickému bádání se věnoval po rozsáhlých studiích biblistiky a judaismu. K islámu nikdy nekonvertoval, ale s uznáním byl přijat jako první Evropan na káhirský al-Azhar a muslimové se na něho často obraceli s důvěrou o radu ve věcech své, tj. islámské víry a práva. ${ }^{23}$

Některé konverze středoevropských Židů k islámu byly od 19. století spojeny s židovským orientalismem, evokujícím souvislost jejich kulturních tradic s Orientem

20 Českého čtenáře tehdy mohlo vzrušovat vylíčení v knize A. J. Mountenay-Jephson, Emín Paša a vzpoura $v$ Aequatorii, kterou přeložila Eliška Krásnohorská. Vyšla v Praze r. 1891.

21 Nejzevrubněji zpracovává jeho životopis Hill, Richard. [1965]. Slatin Pasha. Oxford University Press. (O konverzi k islámu s. 16-17). Jméno Slatin je patrně reminiscencí na české Slatiňany, odkud rodina pocházela.

22 Vambéryho postava je ovšem značně kontroverzní. Mezi ním a jeho někdejším „žákem“ Goldziherem se rozrostlo oboustranně silné nepřátelství. Podrobnosti uvádí Beránek, O. [2010]. s. 30-34 a bibliografie s. 170.

23 Beránek, Ondřej [2010] zachycuje výstižně osobu a islamologické dílo svého protagonisty, ale také „politické a duchovní dějiny Mađarska přelomu 19. a 20. století“. 
a s někdejším plodným soužitím s Araby v muslimském al-Andalusu. O estetických plodech tohoto zaměření - kontrastujícího trochu únikově s vídeňským antisemitismem Lügerovým, mad’arskou tiszaeszlárskou aférou (1882-1883) a obdobně motivovanou protižidovskou hysterií za české hilsneriády (1899-1900) - svědčí některá literární díla - počínaje již Benjaminem Disraelim v Anglii - a pak maurský stavební sloh Nové synagogy v Berlíně (1881), Španělské (1868) a Jeruzalémské (s prvky secese, 1906) v Praze, Tabáční (Dohányi) v Budapešti, zaniklé v podzámčí v Bratislavě a řady dalších židovských sakrálních i světských staveb v evropských městech. ${ }^{24}$ Jiný proud inspirace dávala rozvíjející se orientalistika a snaha o vzájemný prospěch kontaktem s muslimským světem a semitskými př́buznými Araby i jinak než sionistickým stěhováním do Palestiny.

Pozornost si určitě zaslouží dvě osobnosti konvertitů „Lvư“, ${ }^{25}$ jejichž veřejná činnost spadá již převážně do období po rozpadu Rakouska-Uherska. První byl spisovatel, diplomat a inspirátor islámské modernizační obrody Muhammad Asad (1900-1992). Narodil se ve Lvově v židovské rodině, původně se jmenoval Leopold Weiss. Podobně jako Goldziher a Vambery zvládal už od dětství řadu jazyků a také židovské náboženské vědy. Na sionismus pohlížel kriticky, vnímal arabské obavy. Na islám přestoupil v Berlíně roku 1926, říkal, že ho zaujala uspořádanost tohoto náboženskíého učení. Z jeho četných knih vynikají zvláště autobiografická Cesta do Mekky (Road to Mecca, 1954), úvahy o volbě dalšího směru pro islám (Islam at the Crossroads, 1934) a překlad Koránu s exegezí (The Message of the Qur'an, 1980). Významnou politickou činností se Asad zapsal do dějin vzniku a počátků nezávislé existence Pákistánu. Jeho vliv na muslimy v Evropě v některých ohledech přetrvává. Zemřel ve Španělsku. Ve Vídni bylo jeho jménem nazváno náměstí u přidunajského islámského centra. K uznání jeho myšlenek a díla významně přispěl celovečerní film $A$ Road to Mecca. ${ }^{26}$

Stejné jméno, jen jinak německy psané, má také další židovský konvertita k islámu, původním jménem Lev Nussimbaum (1905-1942). Pocházel z bohaté rodiny v Baku, před bolševickou revolucí prchl přes Írán do Německa. Informace o jeho dobrodružném životě jsou rozkolísané; on sám se zálibou fabuloval o vlastní identitě a biografii. Patrně formálně přestoupil na islám na tureckém velvyslanectví v Berlíně v roce 1923. Svou bohatou literární tvorbu podepisoval Essad bej nebo Kurban Said. Islámem dokázal zakrývat své židovství tak úspěšně, že mohl přežívat i v nacistickém Německu a fašistické Itálii. Na středoevropské vrstevníky působil též proislámským vlivem. ${ }^{27}$

24 Židovský orientalismus je spojen s působením mladého Martina Bubera a jeho časopisu Orient. V češtině se o tématu psalo již vícekrát, zájem o ně nově pro veřejnost oživil publicista Jan Lukavec v článku Praha - exotické město Orientu, Lidové Noviny - Orientace, 3. 7. 2010, s. 27.

25 Záliba ve jménu „Lev“ v židovské diaspoře má vícero příčin; především za „mládě lví“ je v závěti Jákoba-Izraela označen Juda (Gn 49: 9); ve většinově slovanské východní Evropě může působit i podoba slova „lev“ se jménem Lévi či Löv, a u M. Asada (L. Weisse) místo původu Lvov (dané podle jména někdejšího panovníka) a také možná emocionální spíše než správná interpretace původního jména Leopold a jiné motivy. Arabské Asad je samozřejmě důstojné a snadno vyslovitelné.

26 Film natočil režisér Georg Misch; byl uveden roku 2008 a vyznamenán několika cenami v různých zemích. V Praze byl promítán na zvláštní projekci na jaře 2010.

27 Prvním knižním životopisem Muhammada v češtině je překlad jeho práce Essad bey, Mohamed. [1935]. Mohamed. Dále pak vyšla ještě kniha Essad Bey a Wolfgang von Weisl. [1938], Alláh je velký. Prvním překladem do češtiny je ovšem Essadův Stalin [1932]. V Národní knihovně je Essad evidován jako Leo Noussimbaum. Dramaticky stylizovaná konstrukce „Essadova“ života vyšla v Americe v roce 2005. Její český překlad je Reiss, Tom [2006]. 
Orientalismus spojený s romantickou zálibou v některých prvcích muslimské kultury, zvláště architektury, nezůstával ovšem omezen jenom na židovskou tvořivost. Tvrdá kritika, kterou postihl tuto obecnější evropskou tendenci Edward Said, ukazuje na její spojení s kolonialismem. V německém prostředí vydala i takové - celkově ojedinělé - architektonické plody jako továrnu na cigarety v Drážđ’anech v podobě mešity (z roku 1907)! Přestupy na islám měly rovněž své nežidovské protagonisty, zvláště z řad orientalistů. V Mađarsku si největší věhlas získal Gyula Germanus (1884-1979). O islám se začal zajímat při studiu tureckých vlivů v uherských dějinách a v seminárích Ignáce Goldzihera, vypracoval se na profesora turečtiny, arabštiny a islámských dějin. Konvertoval k islámu za přednáškového pobytu v indickém Šantinikétanu, kam ho pozval R. Thákur. Přijal islámské jméno Abdalkarím. Postoje a dílo mu vynesly uznání a členství ve vědeckých akademiích několika arabských zemí.

V Československu přestoupilo na islám několik mladých orientalistů nebo učitelů či studentů až koncem 30. let 20. stol., př́ípadně později. Několik českých vzdělanců a vojáků přijalo islám již dříve za působení v Bosně nebo při cestách do muslimských zemí.

O konverzích v opačném směru, tedy od islámu, je málo veřejně př́istupných dokladů. Je známo, že odpadlíka (murtadd) islámská šarí’a trestá, zvláště tehdy, když vyvolává ve společnosti emoce. Pojem apostáze je ovšem ve standardních kompendiích šarî’y definován velmi široce, zahrnuje převážně představy a chování pokládané za bezbožné, a ty také byly někdy v muslimských společnostech disciplinárně tvrdě postihovány. ${ }^{28}$ Ze střední Evropy 19. století nejsou takové případy doloženy.

\section{Faktor Bosna}

Nový způsob začlenění islámu do života střední Evropy vzešel z okupace Bosny a Hercegoviny rakousko-uherským vojskem v roce 1878. Jako podnět zapůsobila povstání proti osmanským agrárním opatřením. Evropské mocnosti reagovaly usnesením Berlínského kongresu dávajícím Vídni mandát $\mathrm{k}$ vojenské akci. Císařská armáda potlačila neočekávaný odpor muslimských obyvatel a ovládla po několika měsících bojů Bosnu s Hercegovinou a sousední sandžak Novi Pazar. Přitom byla zachována de iure svrchovanost Osmanské říše, která vývoj přijímala dosti pasivně. $V$ kázání při páteční modlitbě bylo v Bosně nadále pronášeno jméno osmanského panovníka, avšak jenom jako chalífy, nikoli sultána. Ve správě okupované země se Rakušané de facto neomezovali jen na obecný pořádek a finance, ale přistoupili také k úpravám islámského školství, kontrole nadací (waqfů) a k organizaci náboženského života. Významným krokem v tomto směru bylo od roku 1882 ustavení úřadu hlavy duchovenstva (ra'ís al-'ulamá', turecky reisülulema). Znamenalo to zřejmé oslabení institučních vazeb s Istanbulem. Plně je ukončilo vyhlášení anexe Bosny v roce 1908.

Načasování dozrávajícího expanzívního záměru urychlila mladoturecká revoluce v Istanbulu, jejíž vůdci chtěli v říši (včetně Bosny) vyhlásit parlamentní volby. Rozhodnutí Vídně anektovat Bosnu naráželo u Osmanů sice na odpor, ten byl však nakonec upokojen

28 Podrobně rozebírá problematiku murtaddín soudobé, přísně tradiční kompendium islámského práva všech 4 sunnitských směrů: al-Džazírí, Abd al-Rahmán b. M. Awad. [2001] Kitáb al-fiqh ,alá al-madháhib al-arba'a. Bejrút: Dár Ibn Hazm, s. 1367-1377. Velkou pozornost věnuje otázce majetku a manželství odpadlíka, ale také způsobů pokání. V definici pojmu zřetelně převládá zřetel ke správné víře a k důstojnému zacházení s Koránem, konverze nejsou zdůrazňovány. 
finančním odškodněním a přenecháním novopazarského sandžaku; o ten je pak připravili Srbové za balkánské války v roce 1912. Náboženskou skladbu obyvatelstva dunajského soustátí anexe obohatila o zhruba půl milionu nových spoluobčanů islámského vyznání. Na tuto skutečnost reagoval rakouský parlament v roce 1912 zákonem číslo 59 o „uznání vyznavačů islámu hanafíjského směru jako náboženského společenství. “29 Zákonem byl dovršen právní vývoj, který již dříve vyslovoval muslimům uznání (1874) a dával autonomii jejich institucím (1909). Islamgesetz jim nyní dal rovnoprávné postavení s ostatními církvemi a náboženskými obcemi včetně početně nejsilnější katolické církve. V souladu s občanským právním řádem jim pouze nejsou dovoleny polygamie a šaríatské tělesné tresty (hudúd). Tato omezení jsou dnes běžná ve všech evropských zemích s muslimskými menšinami. V Rakouské republice si Islamgesetz z roku 1912 s některými novelizacemi podržela význam dodnes.

V Uhersku (Zalitavsku) odhlasoval parlament obdobný zákonodárný akt, takzvaný „článek 17“ o oficiálním uznání islámu, v roce 1916. Bylo to za světové války, jíž se Osmanská říše účastnila jako spojenec Ústředních mocností a vyhlásila dokonce Dohodě džihád, což se odrazilo v nadšeném rázu hlasování. Uznání se v tomto zákoně neomezovalo na hanafijský právní směr, ale týkalo se islámu obecně. Rozdíl rakouské a uherské legislativy se projevil ve 30. letech jako závažná nesnáz komplikující snahy muslimské obce dosáhnout uznání v Československu. Bosna nebyla včleněna ani do rakouské, ani do uherské části monarchie, ale byla spravována přímo z Vídně jako corpus separatum. Uherští politici se ji snažili získat; také odtud plynulo jejich nadšené uznání islámu a podpora bosenských přistěhovalců. Tyto záměry ovšem zcela vzaly za své mírem v Trianonu, který Mađarsko zredukoval na pouhou třetinu někdejších Uher.

Určité počty Bosňanů (bosenských muslimů) se ovšem stěhovaly také do Předlitavska, včetně českých zemí. Migraci v tomto směru poněkud tlumil rozmach obchodu a průmyslu, který do Bosny přinesla vyspělá monarchie, a dobrý životní standard bosenských velkostatkářů a obchodníků. Někteří Češi s nimi přicházeli do kontaktu už jako vojáci při tažení v roce 1878, které dodnes připomíná hospodský šlágr Hercegovina s dobově stylovým rytmem a švejkovskou rétorikou o císaři pánu a mohamedánech. Někteří Češi se pak dostávali do Bosny také jako rakouští úředníci a odborníci různých odvětví. Bylo mezi nimi zaznamenáno několik konverzí. Po válce a rozpadu podunajské říše se mnoho Bosňanů vracelo do nové vlasti Království Srbů, Chorvatů a Slovinců (SHS). Kulturní vazby s rakouským i československým vzdělaným světem se nicméně uchovaly. Všimneme si krátce několika výrazných dokladů.

Ve Vídni, odkud byla nová provincie přímo spravována, byl roku 1906 zřízen Bosenský institut pro výchovu tamních elit, a pak také Orientální ústav. V zemi samotné působilo několik významných českých odborníků, zvláště architektů. Z nich je dodnes s úctou připomínán Karel Pařík z Jičínska (zemřel 1942 v Sarajevu). ${ }^{30}$

Nově zřízená univerzitní knihovna v Bratislavě zakoupila v roce 1924 od někdejšího ředitele zemského muzea v Sarajevu dr. Savfeta Bega Bašagiče soubor 266 svazků

29 Gesetz betreffend die Anerkennung des Islam nach hanafitischem Ritus als Religionsgesellschaft, krátce označovaný jako Islamgesetz. Výraz ritus, převzatý z pojmosloví římskokatolické církve, v české orientalistice spíše nepoužíváme a hovoříme o právních směrech nebo školách či arabsky madhhabech.

30 Za informace o česko-bosenských vztazích jsem vděčen zvláště dr. Jiřímu Kudělovi, bývalému českému velvyslanci v Sarajevu. 
arabských, perských a tureckých rukopisů. Řídila se při tom radou íránisty Jana Rypky. Soubor Bašagič soustředil koncem 19. století jednak dědictvím, jednak nákupy po celé pozdější Jugoslávii. Jeho část, která přešla do Bratislavy, zdokumentoval a veřejnosti představil turkolog Jozef Blaškovič. ${ }^{31}$ Poté, co bosenská národní knihovna v Sarajevu byla z velké části zničena za občanské války (1992-1995), bratislavská sbírka dnes představuje mimořádně významnou pokladnici této cenné složky islámské kultury z jihoslovanského regionu..$^{32} \mathrm{~K}$ Bašagičovu souboru patří v Bratislavě ještě 356 starých tisků, převážně tureckých, dosud ne zcela zkatalogizovaných.

Zřetelný hodnotný př́inos z islámského kulturního prostředí Bosny do střední i širší Evropy je spjat s mnohaletým působením Smaila Baliče (1920-2002). Pracoval od roku 1965 v Národní knihovně ve Vídni a početnými monografiemi i mediálními články ukazoval na reálné cesty k dobrým vztahům a smysluplné integraci muslimů, zvláště jihoslovanských a tureckých přistěhovalců, v Evropě. Publikoval německy, bosensky i turecky. Sám hluboce věřící muslim, ženatý s křestłankou, patří k nejzasloužilejším průkopníkům islámsko-křestanského dialogu. ${ }^{33}$ Bosňané, kteří se usadili ve středoevropských zemích, měli různé osudy. V Rakousku stále zůstávají jako místní komunity. Z ostatních zemí se mnozí vraceli do původní vlasti, nebo emigrovali dále do Evropy: hned po 1. světové válce po vzniku SHS, z Mađ’arska pak také v roce 1956. Za občanské války 1992-1995 středoevropské země přijaly dočasně mnoho bosenských azylantů (v ČR včetně kvalifikovaného imáma Džaafara Gračiče), kteří po daytonských dohodách zase odcházeli. Bosenský faktor zůstává v regionu živý, a to převážně jako prvek působící v duchu umírněného euroislámu. Z Bosny přicházejí také pozoruhodné impulzy architektonických inovací ve stavbě mešit v duchu označovaném za modernistický architektonický euroislám (zvl. Alen Jasarevič). ${ }^{34}$

\section{Nové komunity v nových, národních státech}

Se zánikem Rakouska-Uherska začíná ve střední Evropě nová historická fáze i pro organizovanou př́tomnost muslimů. Důraz na národní identitu dával ovšem nejenom směr a dějinotvornou sílu Wilsonovu principu sebeurčení, ale také vytěsňoval do pozadí činitele náboženské. Na čas nabyl nacionalismus vrchu i na muslimském Blízkém východě: v arabské revoluci proti Osmanské ř́rši za války, v kemalistické revoluci v Turecku i jinde a jindy. Do jaké míry je vlastně vhodné hovořit ve středoevropském kontextu o utváření muslimských komunit? Vyskytují se pochybnosti, zda jde o reálné, nebo jen pomyslné (imagined) sociální entity. Stefano Allievi si všímá skutečnosti, že se v Evropě u přistěhovalců vědomá společenství formovala na etnicko-náboženském základě a teprve s druhou generací nabývala náboženskou povahu, přesahující národní hranice. V takovém případě

31 Blaškovič, Jozef (ed.). [1961]. Stojí za zmínku, že editor Blaškovič (1910-1990), docent turkologie na Filozofické fakultě UK v Praze, se hlásil k rodinným kořenům vycházejícím z kumánského etnika.

32 Teprve v listopadu 2010, po pěti letech studia, uveřejnila Národní knihovna v Bělehradě elektronický katalog svých více než 600 islámských rukopisů. Viz http://sites.google.com/site/acatalogueofislamicmanuscripts/home.

33 Jeho životopis a hodnocení viz in. Bsteh, Petrus. Smail Balič, ein Muslim aus Mostar ales europäischer Brückenbauer, Religionen unterwegs Nr. 2004/1, Wien, s. 24-26.

34 Welzbacher, Ch. [2008]. Pozoruhodné je zvlášte Jasarevičovo Islámské centrum v Penzbergu, městečku na jihu Bavorska, bylo otevřeno v roce 2005. Alen Jaserevič je mladý Bosňan žijící v Spolkové republice Německo. 
hovoří o neo-komunitách. ${ }^{35}$ Někteří autoři zase používají termín komunita v užším slova smyslu jako označení okruhu věřících kolem určité mešity. V diskursu o evropském islámu se ujímá terminologie vytvářející jakousi symetrii s křest̉anskými církvemi: komunita je obdoba farnosti, imám obdobou faráře.

Viděli jsme, že v minulosti společný etnický a náboženský základ umožňoval organizovanou soudržnost jenom u polsko-litevských Tatarů a krátce existenci muftiáti̊ ve vrcholném období osmanské vlády v Uhrách. Teprve v nových, národních státech vyvstaly snahy o založení muslimských náboženských organizací. V Československu podalo takovéto sdružení, založené v Praze v letech 1934-1935, žádost o úřední registraci, která však narazila na rozdílnost dřívější formulace uznání z roku 1912 pro České země (hanafíjského ritu) a z roku 1916 pro Slovensko (islám obecně). ${ }^{36}$ Za komunistického režimu neměla registrace žádnou šanci. Po přechodu k demokracii a po rozdělení státu na dvě republiky úřední registrace v obou vázne pro malý počet signatářũ: v ČR dosáhl El Ittihad el Islami od roku 2004 pouze registrace druhé kategorie, předpokládané jako provizorní; počet muslimů dosahuje možná až 15 000, praktikujících je ovšem méně, odhadem asi 5 000. K plnoprávné registraci je ovšem třeba opatřit žádost 10000 podpisy.

Na Slovensku zůstává registrace zatím zcela nedosažitelná vzhledem k podmínce doložení žádosti podpisy dokonce 20000 dospělých žadatelů. Při sčítání lidu v roce 2001 se k islámskému vyznání přihlásilo 1212 občanů; muslimové sami odhadují svůj počet v zemi asi na $5000 .{ }^{37}$ Někteří ze země odcházejí, podle názoru představitele jejich obce také proto, že se na Slovensku zatím neustavila náležitá muslimská komunita, která by pečovala o jejich duchovní a kulturní potřeby. ${ }^{38}$

V Polsku byl islám oficiálně uznán již v roce 1936. Příslušný zákon požadoval, aby do kázání (chutba) před páteční kongregační modlitbou byla vkládána prosba za požehnání pro prezidenta republiky. Tataři se chovali vždy loajálně vůči většinovým Polákům, sdíleli s nimi i boje za 2 . světové války. Po válce se muslimská menšina rozrostla a diversifikovala. Do země přijížděli studenti z arabských zemí a po roce 1989 se země otevřela také přistěhovalcům z Balkánu a z postsovětského prostoru. Oficiální veřejnoprávní uznání se dostalo několika muslimským organizacím. Věřící tatarského původu jsou sdruženi převážně v Muzułmańskem Związku Religijnem, a to v počtu mezi 4 000-6 000 osobami. Ostatní muslimové, imigranti z nedávných let, jsou sdruženi v několika vlastních, náležitě uznaných sdruženích a spolcích. Jejich počet se udává mezi 10000 až $20000,{ }^{39}$ v samotné Varšavě jich žije více než 10 000. Údaje se v různých

35 Allieviho stat' „Islam in the public space: social networks, media and neo-communities“ in: Allievi, S. a Nielsen, J. [2003], s. 1-27. Luboš Kropáček se při své účasti na evropských iniciativách křesţansko-muslimského dialogu setkal několikrát u muslimských partnerů s názorem, že vzájemné interaktivní vazby jejich souvěrců (v různých evropských zemích) jsou př́liš slabé na to, aby opravňovaly hovor o komunitě. Termín se přesto pužívá, a to jak v širším, tak v užším významu, např. mosque community jako paralela ke křestanské farnosti.

36 Složité peripetie právního postavení muslimské obce v ČSR a v nástupnické ČR líčí Mendel, Miloš [1998] a Mendel, Miloš et al. [2007].

37 Problém je vyložen a podrobně analyzován v článku Pirický, Gabriel [2010]. Z téhož zdroje jsou také uvedená čísla.

38 Názor vyjádřil v osobním rozhovoru představitel bratislavského Združenia priatelov islamskej literatúry Abdulvahab al-Sbenaty.

39 Údaje A. Nalborczyk, in. Parzymies, A. [2005], s. 230. Stručný přehled tématu podává tatáž autorka v př́íspěvku Islam v Pol'sku - 600 rokov moslimskej prítomnosti, in. Moravčíková, Michaela - Lojda, Miroslav [2005], s. 60-67. 
zdrojích značně liší. Oficiální sčítání lidu v roce 2002 nezahrnovalo otázku o náboženském vyznání.

V Mađ’arsku nezískali muslimové žádný oficiální status ani v meziválečném, ani v komunistickém období. Dočkali se ho až v procesu demokratizace. K registraci náboženského společenství stačí žádost se 100 podpisy. ${ }^{40}$ Počet muslimských usedlíků se odhaduje na 4 000. Jejich nejznámější organizace, registrovaná Zákonem č. 4 z roku 1990, je v dikci tohoto aktu označena egyház, což vlastně znamená „církev“.

V Rakousku bylo právní postavení islámu upraveno v roce 1979 na základě zákona z roku 1912. Po imigracích skupin Bosňanů prosperující ekonomika země absorbovala velký počet přistěhovalců za prací (Gastarbeiter) z Turecka i některých jiných zemí. Mají své organizace. Katolická církev projevuje zájem o dobré vztahy s muslimskými spoluobčany a $\mathrm{v}$ jednotlivých spolkových zemích pověřuje některé duchovní péčí o kontakty s tamní muslimskou komunitou. V Rakousku se konají významné akce mezináboženského dialogu. Nezapomenutelnou roli na tomto poli míval kardinál Franz König. Celkově se odhaduje, že v Rakousku žije asi 340000 muslimů, představují tedy něco přes $4 \%$ obyvatelstva republiky.

Muslimové v našem sledovaném regionu se střetávají s obdobnými problémy jako jejich souvěrci jinde v Evropě jen velmi zrrídka. Nevyskytuje se například problém zahalování žen. Větší zahalení než prostý hidžáb se objevuje jen ojediněle u pacientek či žen pacientů v lázeňských městech, jako jsou např́klad české Teplice nebo slovenské Pieštany. Citlivou otázkou, která čas od času rozčeří vztahy mezi domácí většinou a muslimskými příchozími, je však výstavba nových mešit. ${ }^{41} \mathrm{~V}$ Českých zemích byla po delších diskusích otevřena nová mešita v Brně (1998) a pak v Praze (1999). Obě jsou bez minaretů, na ty nebylo vydáno stavební povolení. V dalších městech, kde žijí skupiny muslimů, zvláště studentů, mají $\mathrm{k}$ dispozici jen modlitebny. $\mathrm{V}$ některých případech nebylo postavení mešity povoleno; pozornost vzbudily zvláště diskuse o návrhu stavět mešitu v Teplicích, kam jezdí každoročně poměrně početná arabská lázeňská klientela. V roce 2010 vyvolaly kontroverze návrhy stavět mešitu v Hradci Králové a větší mešitu v Brně.

Na Slovensku nebyla doposud žádná mešita vystavěna. Místní muslimové ř́kajî s neskrývaným steskem, že Bratislava je jediným hlavním městem v Evropské unii, které nemá mešitu. (Muslimové z Petržalky se chodí v pátek modlit do turecké džámije v blízkém Hainburgu v Rakousku.)

Internetové i tištěné zdroje uvádějí, že v Polsku fungují 4 mešity a kromě nich větší počet islámských modliteben ve velkých městech. Na jaře 2010 se rozpoutaly diskuse a protestní akce v souvislosti se záměrem vystavět poblíž centra Varšavy velkou mešitu s doprovodnými zařízeními (knihovna, přednáškový a multimediální sál, kavárna). Vedoucí představitel nově vytvořené Muslimské ligy Samír Ismáíl v zájmu smírného řešení nabídl, že mešita by měla mít minaret vysoký pouze asi 15 metrů, přestože stavební povolení schválilo výšku více než 20 metrů. Má jít každopádně o druhou mešitu v polské metropoli; první byla otevřena již v roce 1993.

40 Lederer, Gyorgy [2002], s. 15.

41 Spory o mešity v Evropě se zabývá Césari, Jocelyne [2005], Mendel, Miloš et al. [2007] a nověji Welzbacher, Christian [2008], sledující zvláště estetické inovace mešit v Evropě. Je př́značné, že věnuje pozornost novým mešitám v Bavorsku, Sasku, Bosně a také v chorvatském Záhřebu, málo však v našem sledovaném regionu. 
V Mađarsku mohou místní muslimové v historickém župním městě Petikostelí (Pécs) využívat na páteční modlitbu starý osmanský džámi' (turecky psáno cami). V Budapešti nebyl realizován projekt výstavby islámského centra na budínském Rưžovém vrchu u historické hrobky súfijského šejcha Gül Baby. V metropoli však funguje velká mešita se společenským a kulturním centrem Dár as-Salám. V ostatních velkých mad’arských městech se muslimové scházejí k modlitbě v soukromých bytech. V dnešním Rakousku se podle některých údajů hovoří až o 200 mešitách. Velký početní nárůst byl zaznamenán zvláště v posledních 20 letech. Číslo ovšem zahrnuje široké spektrum od jednoduchých modliteben někde $\mathrm{v}$ zadním dvoře obytného domu až po prestižní Islámské centrum vybudované v letech 1977-1979 za saúdské finanční podpory ve Vídni (Das Islamische Zentrum Wien). Muslimové tak s klidem v duši mohou zapomenout na některé nesplněné sliby z minulosti: po vydání Islamgesetzu byl deklarován záměr postavit $\mathrm{v}$ hlavním městě císařství reprezentační mešitu. Císař na tento účel věnoval 25000 korun a město Vídeň věnovalo pozemek. ${ }^{42}$ Projekt zhatila světová válka. V někdejším hlavním městě monarchie, která patřila dlouho k úhlavním protivníkům muslimské Osmanské říše, má dnes svou východoevropskou kancelář Světové shromáždění muslimské mládeže (WAMY), šírící saúdskou islámskou propagaci a účelovou podporu do středoevropských zemí. Působí zde také Pomocná agencie třetího světa (TWRA), která sponzoruje šíření islámských knih; za války v Bosně dodávala ovšem muslimské straně také zbraně. Na druhé straně se v zemi objevují některé islamofobní tendence, v politické rovině je představoval Jörg Haider a jeho strana; stavěl se např́́klad proti výstavbě mešit v Korutanech. Obecně se zdá, že Rakousko se svou nejsilnější muslimskou menšinou v regionu a svou starší i novější historickou tradicí v dobrém, problematickém i nedobrém zůstává i dnes - přestože formálně nepatří k „Visegrádské čtyřce“ - v tematice našeho zkoumání důležitým barometrem. ${ }^{43}$

42 Balič, Smail [1995], s. 26.

43 Americká novináŕka Leora Moreno publikovala po rozsáhlém výzkumu v ČR, na Slovensku a v Madarsku fundovanou stat v internetovém časopise New Presence (viz www.new-presence.cz, Autumn 2010) s titulem Fearing the Future: Islamophobia in Central Europe. Naznačuje politování, že region s malou prítomností muslimů, odkud by mohly prííít impulzy proti islamofobii, sleduje dosti mechanicky nálady panující v Západní Evropě. 


\section{Literatura}

Allievi, Stefano a Nielsen, S. Jorgen (eds.). [2003]. Muslim networks and transnational communities in and across Europe. Leiden. Boston: Brill.

Balič, Smail [1995]. Zur Geschichte der Muslime in Österreich. In Heine, S. (ed.), Islam zwischen Selbstbild und Klischee. Eine Religion im österreichischen Schulbuch. Köln - Wien.

Bašagič Beg, Savfet. [1912]. Bošnjaci I Hercegovci u islamskej književnosti. Prilog kulturnoj historii Bosne i Hercegovine. Sarajevo.

Beránek, Ondřej. [2010]. Ignác Goldziher - vězeň z Budapešti. Brno: CDK.

Blaškovič, Jozef (ed.). [1961]. Arabische, Türkische und Persische Handschriften der Universitätsbibliothek in Bratislava. Bratislava: Univerzitná knižnica.

Bohdanowicz, L. - Chazbijewicz, Selim. - Tyszkiewicz, J. [1997] Tatarzy muzułmanie w Polsce. Gdańsk.

Borawski, Piotr - Dubiński, Aleksander. [1986]. Tatarzy polscy. Dzieje, obrzędy, legendy, tradycje. Warszawa.

Césari, Jocelyne. [2005]. Mosque Conflicts in European Cities: Introduction, JEMS, 31(6). s. 1015-1024.

Coles, Paul. [1968]. The Ottoman Impact on Europe. London: Thames and Hudson.

Dassetto, Felice - Ferrari, Silvio - Maréchal, Brigitte. [2007]. Islam in the European Union: What's at Stake in the Future. Brusel: European Parliament.

Donia, Robert J. [2009]. Sarajevo. A Biography. London: Hurst.

Gombár, Eduard [1999]. Osmanské dědictví. Šíření islámu na Balkáně. In. Obuchová, L. (ed.). Variace na Korán. Islám v diaspoře. Praha: Orientální ústav, s. 53-86.

Hanuš, Jiří (ed.). [2002]. Dějiny kultury a civilizace Západu v 19. století. Brno: CDK.

Horváth, Pavol - Kopčan, Vojtech. [1971]. Bratislava: Slovenské pedagogické nakladatelstvo.

Hourani, Albert [1991a]. Islam in European Thought. Cambridge UP.

Hourani, Albert [1991b]. A History of the Arab Peoples. London: Faber and Faber; český překlad Dějiny arabského světa. [2010]. Praha: Nakladatelství Lidových novin.

Inalcik, Halil with Quataert, Donald. [1994]. An Economic and Social History of the Ottoman Empire, vol. two, 1600-1914. Cambridge University Press.

Kropáček, Luboš. [1995] Alois Musil on Islam. Archiv Orientální 63, s. 401-409.

Kropáček, Luboš. [2001]. Islám a Západ. Historická pamět a současná krize. Praha: Vyšehrad.

Lederer, Gyorgy. [2002]. Islam in Post-Socialist Hungary. ISIM Newsletter 11, s. 15.

Kuschel, Karl-Josef. [1998]. Vom Streit zum Wettstreit der Religionen. Lessing und die Herausforderung des Islam. Düsseldorf: Patmos Verlag.

Maréchal, Brigitte - Allievi, Stefano - Dassetto, Felice - Nielsen, Jorgen. [2003]. Muslims in the Enlarged Europe. Religion and Society. Leiden: Brill.

Mendel. Miloš. [1998]. The Islamic Religious Community in Bohemia and Moravia (1934-1945). In: Archív orientální 66, 1998, No. 2.

Mendel, Miloš - Ostřanský, Bronislav - Rataj, Tomáš. [2007]. Islám v srdci Evropy. Praha: Academia.

Miśkiewicz, Alego [1990] Tatarzy polscy 1918-1839. Życie społeczno-kulturalne i religijne. Warszawa.

Moravčiková, Michaela - Lojda, Miroslav. [2005]. Bratislava: Ústav pre vztahy štátu a církví.

Pallmer, Adam [1996]. Úpadek a pád osmanské ř́še. Panevropa.

Parzymies, Anna (ed.). [2005]. Muzułmanie w Europie. Warszawa: Wydawnictwo Akademickie Dialog.

Pirický, Gabriel. [2010]. Restrictive Legislation towards Numerically Small Religions in Slovakia: the Case of the Muslim Community. European Yearbook of Minority Issues Vol. 7, 2007/8, 2010, Leiden: Brill. s. 717-729.

Ramadan, Tariq. [2004]. Western Muslims and the future of Islam. Oxford. 
Rataj, Tomáš. [2002]. České země ve stínu půlměsíce. Obraz Turka v raně novověké literatuře $z$ českých zemí. Praha: Scriptorium.

Reiss, Tom. [2006]. Orientalista. Praha: BB/art.

Said, Edward. [1978]. Orientalism. New York: Random House.

Tyszkiewicz, Jan. [1989]. Tatarzy na Litwie i w Polsce. Warszawa: Państwowe Wydawnictwo Naukowe.

Waardenburg, Jacques. [1963]. L'islam dans le miroir de l'Occident. Paris: Mouton.

Welzbacher, Christian. [2008]. Euro Islam Architecture. New Mosques in the West. Amsterdam: Sun.

Prof. Luboš Kropáček (1939), orientalista. Přednáši na Univerzitě Karlově na Filozofické fakultě a na teologických fakultách. Vydal několik knih, zvláště Duchovní cesty islámu (4. vyd. 2006), Islámský fundamentalismus (1996), Blízký východ na přelomu tisíciletí (1999), Islám a západ (2002) a Súfismus. Dějiny islámské mystiky (2008). 